\title{
'To be tensed or not to be tensed?' The case of Vietnamese
}

\author{
Trang Phan \\ UNIVERSITY OF LANGUAGES AND INTERNATIONAL STUDIES \\ VIETNAM NATIONAL UNIVERSITY, HANOI \\ chengnn85@gmail.com
}

Nigel Duffield

KONAN UNIVERSITY

nigelduffield@gmail.com

\begin{abstract}
In this paper, we scrutinise the interpretation and distribution of a number of morphemes that serve as means of expressing temporal/aspectual relations in Vietnamese, investigating whether they should treated as genuine tense and aspect markers. The main goals of the study are two-fold: (i) empirically, to offer a comprehensive description of Vietnamese tense and aspect, in both pre-verbal and post-verbal domains; (ii) theoretically, to offer new pieces of evidence supporting the claim that Tense and Aspect exist as independent functional categories in Vietnamese.
\end{abstract}

\section{Introduction}

This paper considers the applicability of the functional categories of Tense and Aspect in the analysis of Vietnamese clause structure. There is obvious disagreement in the research literature ${ }^{1}$ concerning whether and/or how Tense and Aspect are realised in Vietnamese. On the one hand, there are some scholars who categorically deny the existence of tense as a

\footnotetext{
${ }^{1}$ See Trần Kim Phượng (2008) for a comprehensive review of traditional descriptions of tense/aspect in Vietnamese.
} 
grammatical category in Vietnamese. This position is illustrated by Cao Xuân Hạo's assertion (1998): ${ }^{2}$

'Tiếng Việt tuyệt nhiên không có thì... Khi cần định vị một sự tình trong thời quá khứ hay hiện tại, tiếng Việt dùng đến những khung đề có ý nghĩa từ vựng thích hợp như: xưa kia, trước đây, hiện nay, bây giờ'3 (Cao 1998:10)

This view is based on the observation that Vietnamese lacks the inflectional morphemes that commonly express temporal relations in Western European languages; instead, contextual or adverbial elements are usually recruited to mark such distinctions:

(1) a. Ngày mai tôi viết bài

Tomorrow $1 \mathrm{~S}$ write paper

'I will write papers tomorrow.'

b. Hôm qua tôi viết bài

Yesterday $1 \mathrm{~S}$ write paper

'I wrote papers yesterday.'

A contrary line of opinion, on the other hand, states that Vietnamese actually has Tense, in as much as Vietnamese does dispose of a number of functional morphemes - albeit free morphemes - which add a certain temporal value to the verb to which they are combined. Analyses of this kind typically focus on the three pre-verbal elements: đã đang, sẽ whose identification is often influenced by reference to Western European linguistics categories: see especially Lo Cicero (2001).

(2) a. Tôi đãa viết bài

$1 \mathrm{~S}$ DA write paper

'I wrote papers.'

b. Tôi đang viết bài

1S DANG write paper

'I am writing papers.'

c. Tôi sẽ viết bài

1S SE write paper

'I will write papers.'

From this perspective, đã is usually assumed to signal the past tense, se the future tense and đang the present tense. For instance, Thompson (1965) claims that:

2 See also Nguyễn Đức Dân (1996) for a similar viewpoint.

3 'Vietnamese has no tense at all ... In order to locate a situation in the past or at the present time, Vietnamese employs relevant lexical adverbials such as: long ago, previously, nowadays, at present.' (Translation ours). 
'The words đã 'anterior' and sẽ 'subsequent' are tense markers' (Thompson 1965:206)

while Phan Khôi (1955) notes that:

'Những chữ như đã, đang, sẽ mới thật sự là biểu diễn được cái hồn của thì. Vì nó $[. .$.$] có sức làm nổi bật lên cái ý$ nghĩa vững chắc sâu sắc của quá khứ, hiện tại, vị lai.'4 (Phan, K 1955/1997:112)

A third, more nuanced view proposes that those three pre-verbal morphemes are markers of both Tense and Aspect (Trần Trọng Kim et al 1940, Nguyễn Minh Thuyết 1995, Panfilov 2002, Trinh 2005, Duffield 2007, 2013). Specifically, whereas $s \tilde{e}$ is fairly consistently considered as a future tense marker, đang is widely accepted as a progressive/durative aspect marker, đã is analysed as being ambiguous between a past tense marker or a perfect aspect marker, depending on the grammatical context. Under this view, Vietnamese not only has Tense but also Aspect. However, most previous analyses (except Nguyễn Văn Thành 2003, Cao 2000 and Fukuda 2007) have tended to ignore post-verbal result-denoting particles such as hêt ('end'), xong ('finish'), ra ('out'), được ('get'), etc.

(3) Tôi đã viết xong bài $1 \mathrm{~S}$ DA write finish paper

'I have written up papers.'

Even Nguyễn Văn Thành (2003), Cao (2000) and Fukuda (2007) do not take into account the hierarchy of these post-verbal elements, or how they interact with the pre-verbal elements.

The purpose of our study, therefore, is two-fold: (i) to address an empirical gap by closely examining both genuine pre-verbal and postverbal temporal/aspectual morphemes as listed in (4), carefully distinguishing them from other markers, and systematically investigating their interactions with one another; (ii) based on this examination to argue that Tense and Aspect indeed exist in Vietnamese as distinct functional categories.

4 'The words đã, đang, sẽ truly represent the spirit of tense. For they [...] are capable of highlighting the solid and profound meaning of the past, the present, and the future'(translation ours). 
(4) The list of temporal and aspectual morphemes in Vietnamese:5

$\begin{array}{lll}\text { Preverbal: } & \text { the future } & \text { sẽ } \\ & \text { the perfect } & \text { đã } \\ \text { the durative dang } & \text { đang } \\ \text { Post-verbal: } & \begin{array}{l}\text { the completive } \\ \text { hết (end), xong (finish), ra (out) }\end{array}\end{array}$

The main claim of the paper is that Vietnamese temporal/aspectual morphemes are genuine tense/aspect markers. This is based on three main pieces of evidence. First, it will be shown although they are not inflectional, these morphemes are not peripheral either, they are still closely associated with the verb (section 3). Second, it will be shown that these morphemes are not as optional as has commonly been assumed: there are contexts where their absence results in ungrammaticalty (section 4). Third, it will be shown that they are strictly ordered, following the universal functional hierarchy of tense and aspect cross-linguistically (Cinque 1999) (section 5). We conclude the paper by discussing the implications of those findings for semantics-syntax interfaces and typological comparison.

Before beginning, it is useful to briefly summarize broader theoretical contexts of the analysis in the following section.

\section{Theoretical background}

In this paper - see also Duffield (2013) - we adopt Klein (1994)'s semantic interpretation of tense and aspect. Klein (1994), on the basis of his well-formed criticism of the traditional approach, proposes a timerelational analysis, which in a way brings aspect on a par with tense. In particular, 'both tense and aspect are defined in terms of temporal relations, such as before, after, simultaneous they only differ in what is related to what' (Klein 1994:3). There are three distinguished times: the time at which the utterance is made (TU), the time span at which a situation obtains (T-SIT or time of situation) and 'the time span to which the speaker's claim is confined' (TT or topic time) (Klein 1994:6). Tense does not apply to the relation between TSit and TU as in the widely held assumptions about tense but the one between TT and TU. Aspect, on the other hand, concerns the temporal relation between TT and T-SIT. The following diagram shows an example of the representation of major tense and aspect categories in this framework:

5 The list of putative post-verbal aspectual markers varies among researchers (Nguyen 2003, Cao 2003, Duffield 1999, Fukuda 2007, Phan 2013b). However, there is a widely accepted assumption that they can be divided into two groups: the completive group and the resultative group. 
(5) TENSE:

(6)

$\begin{array}{cll}\text { Present tense: } & \text { TU INCL } & \text { TT } \\ \text { Past tense: } & \text { TU AFTER } & \text { TT } \\ \text { Future tense: } & \text { TU BEFORE } & \text { TT } \\ \text { ASPECT } & & \\ \text { Imperfective: } & \text { TT INCL } & \text { TSit } \\ \text { Perfective: } & \text { TT AT } & \text { TSit } \\ \text { Perfect: } & \text { TT AFTER } & \text { TSit } \\ \text { Prospective: } & \text { TT BEFORE } & \text { TSit }\end{array}$

In addition to Klein's distinction of tense and aspect, we also adopt Smith (1997)'s two-way distinction of Viewpoint Aspect and Situation Aspect. Whereas Viewpoint aspect (or grammatical aspect) gives temporal perspective to the situation that the verbs describe, such as whether the situation is viewed in its entirety or in its partial stages (Perfect, perfective, progressive, etc.); Situation aspect (also known as Lexical Aspect, or Aktionsart) gives the inherent temporal properties of situations that the verbs describe (State, Activity, Achievement, Accomplishment) (Vendler 1957).

We further adopt a syntactic approach to the hierarchy of tense and aspect. In particular, it is assumed that different kinds of tense and aspect markers are arranged in a universal hierarchical order; following Cinque (1999): 6

(7)

$\left[\operatorname{Mood}_{\text {speech act }}\left[\operatorname{Mood}_{\text {evaluative }}\left[\operatorname{Mood}_{\text {evidential }}\left[\operatorname{Mod}_{\text {epistemic }}[\mathrm{T}\right.\right.\right.\right.$ (Past) $[\mathrm{T}($ Future $)$

$\left[\operatorname{Mood}_{\text {irrealis }}\left[\operatorname{Mod}_{\text {necessity }}[\operatorname{Mod}\right.\right.$ possibility $[$ Asphabitual $[$ Asp delayed $[$ Asp predispositional

$\left[\right.$ Asprepetetive (I) $\left[\mathrm{Asp}_{\text {frequentive (I) }}\left[\mathrm{Mod}_{\text {volitional }}\left[\mathrm{Asp}_{\text {celerative }}\right.\right.\right.$ (I) $[$ Aspterminative

$\left[\mathrm{Asp}_{\text {continuative }}\left[\mathrm{Asp}_{\mathrm{perfect}}\right.\right.$ (?) $\left[\mathrm{Asp}_{\text {retrospective }}\left[\mathrm{Asp}\right.\right.$ proximative $\left[\mathrm{Asp}_{\text {durative }}[\mathrm{Asp}\right.$ generic/progressive

$\left[\right.$ Asp prospective $\left[\mathrm{Asp}\right.$ inceptive (I) $\left[\mathrm{Mod}_{\text {obligation }}\left[\mathrm{Mod}_{\text {ability }}[\mathrm{Asp}\right.\right.$ frustrative/success

$\left[\operatorname{Mod}_{\text {permission }}\left[\right.\right.$ Asp $_{\text {conative }}\left[\right.$ Asp completive (I) $_{\text {ind }}\left[\right.$ Voice $\left[\right.$ Asp $_{\text {celerative (II) }}[$ Aspinceptive (II)

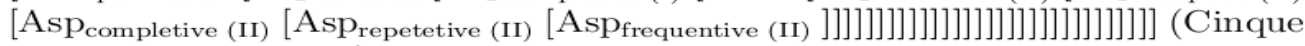

1999, 106; 2001, 153).

Crucially, the hierarchy is detected by a variety of diagnostics, among which the placement of the morphemes under consideration with respect to adverbs and negation is assumed to be a reliable diagnostic to find out the sequence of the functional categories they encode (Pollock 1989, Cinque 1999, 2006, Cinque \& Rizzi 2008). With the cartographic syntactic approach, the paper thus also aims to test the validity of Cinque's (1999) proposal in light of evidence from Vietnamese.

\section{Non-peripherality}

One of the main reasons given by those that deny the existence of tense and/or aspect as a functional category in Vietnamese such as Cao (1998),

6 See Hengeveld $(1989,2011)$, Foley \& Van Valin (1984) for alternative semantic approach to the hierarchy of tense and aspect. Crucially, both the syntactic approach and the semantic approach lead to a strikingly similar hierarchy. 
Nguyen (1996) is that unlike Indo-European languages, Vietnamese lacks inflectional morphology of any kind and generally employs clauseperipheral contextual or adverbial elements to signal temporal or aspectual distinctions.

In this paper, we adopt Binnick's (2001) distinction between temporality and aspectuality inside the verb and temporality and aspectuality outside the verb. The former refers to those cases in which tense and aspect are marked morphologically by use of verbal affixes or of verbal auxiliaries and particles which have close syntactic relation with the verb. The latter refers to those cases in which temporal/aspectual relationships are signalled by expressions headed by adverbs, prepositions, nouns.

Keeping Binnick's distinction in mind, it should be clear that Vietnamese not only relies on peripheral temporal/aspectual expressions. Vietnamese tense/aspect morphemes listed in (4), though are not inflectional, are still closely associated with the verb and clearly distinct from peripheral devices.

First, it is well-documented that the Vietnamese temporal/aspectual morphemes are not inflectional. As can be seen in the example (2), repeated here as (8), the form of the verb viét ('write') stays the same no matter what tense it refers to.

(8) a. Tôi đã viết bài. 1S DA write paper 'I wrote papers.'

b. Tôi đang viết bài. 1S DANG write paper 'I am writing papers.'

c. Tôi sẽ viết bài. 1S SE write paper 'I will write papers.'

Moreover, it can also be seen in (9) that even within the same time frame (the present tense in this case), the verb still lacks person and number inflection.

(9) a. Tôi đang viết bài 1S DANG write paper

'I am writing papers.'

b. Cô-ấy đang viết bài 3S.F DANG write paper

'She is writing papers.'

c. Họ đang viết bài 3PLDANG write paper 'They are writing papers.' 
In English, the subject and the verbal auxiliary agree in person and number. But in Vietnamese, the auxiliary dang remains the same form no matter what person and number specification of the subject is.

These examples indicate two crucial facts about Vietnamese: (i) it does not mark tense or any functional categories on the verb stem; and (ii) the temporal/aspectual markers in Vietnamese are not affixes, but free morphemes.

It is important to note that the pre-verbal and post-verbal tense/aspect markers listed in (4) are clearly distinguished from peripheral devices such as time-related adverbs both in terms of distribution and interpretation.

A distinction can be drawn between truly tense/aspect markers (the trio: the future morpheme se्e, the perfect morpheme đã , the durative đang) and other time-related adverbs, which are mistakenly listed as tense/aspect markers in some works (Bùi Đức Tịnh 1967, Đào Thản 1979, Nguyễn Minh Thuyết 1995, Nguyễn Kim Thản 1997, Duffield 2007, Trần Kim Phượng 2008, Do-Hurinville 2009), such as tìng (remote past), mói (recently), vìa (just), sắp (near future: to be about). The crucial criterion is based on their different interaction with the sentential negation không.

Evidence of this distinction is provided by negative contexts, where although both the two groups can precede the negator, only the former can bear a sentential negation reading (in the case of the latter set, the sentence must be interpreted as constituent-negation).

Declarative sentences

(10) a. Nó sẽ làm việc đó 3s fut do job dem 'He will do it.'

(11) a. Nó đã làm việc đó 3 s ant do job dem 'He did it.'

(12) a. Nó đang làm việc đó 3s dur do job dem 'He is doing it.'

(13) a. Nó tùng làm việc đó 3s adv do job dem 'He used to do it.'

(14) a. Nó mới làm việc đó $3 \mathrm{sadv}$ do job dem 'He has just done it.'

(15) a. Nó vừa làm việc đó 3s adv dojob dem 'He has just done it.'
Negative sentences

b. Nó sẽ không làm việc đó 3s fut neg do job dem 'He won't do it.'

b. Nó đã không làm việc đó 3s ant neg do job dem 'He didn't do it.'

b. Nó đang không làm việc đó 3s dur neg do job dem 'He isn't doing it.'

b. Nó tùng không làm việc đó 3s adv neg do job dem NOT: 'He didn't use to do it'. BUT: 'He used to not do it.'

b. Nó mói không làm việc đó 3s adv neg do job dem NOT: 'He hasn't just done it.' BUT: 'He has just not doing it.'

b. Nó vừa không làm việc đó 3s adv neg do job dem NOT: 'He hasn't just done it.' BUT: 'He has just not doing it.' 

(16) a. Nó sắp làm việc đó $\mathrm{b}$. Nó sắp không làm việc đó $3 \mathrm{~s}$ adv do job dem $3 \mathrm{~s}$ adv neg do job dem 'He is about to do it.' $\quad$ NOT: 'He isn't about to do it.' BUT: 'He is about not to do it.'

As illustrated by the above examples, the temporal adverbs only modify the predicate directly, and do not occur as high as the three genuine tense/aspect markers đã , đang, se and thus, are excluded in our analysis.

Another factor in distinguishing the two groups is related to their semantics. Unlike the three markers đã, đang, sẽ; the adverbs vìa, mói, tùng, sắp not only anchor the situation time with respect to the utterance time (before, after, or at), but also have an additional meaning component. Similar to canonical adverbs which act as modifiers of verbs expressing manners and various properties of the event, these temporal adverbs also serve as modifiers which tell us how far from the utterance time the situation time is located: vìa, mói are somehow equivalent to recent past, tìng to remote past, sắp to near future in English (see also Panfilov 2008, Trần Kim Phượng 2008). Therefore, both distribution-wise and interpretation-wise, the three genuine pre-verbal tense/aspect markers are distinct from temporal adverbs.

With respect to the post-verbal domain, a distinction should be drawn between genuine completive/resultative particles and the aspect-related adverb rồi ('already'), which is also often mistakenly listed as an aspect marker (as in Cao 2000, Trần, K.P 2008, Trinh 2005, a.o.). Although both telic particles and the adverb rồi ('already') appear postverbally, the completive markers always obligatorily precede the peripheral adverb rồi.
a. Tôi
đã viết
bài
xong rồi
1s DA write paper finish already
'I have already written up (the) papers.'
$\begin{array}{lllll}\text { b. * Tôi } & \text { đã } & \text { viết } & \text { bài rồi xong } \\ \text { 1s } & \text { DA } & \text { write } & \text { paper already finish }\end{array}$

(Intended:): 'I have already written up (the) papers.'

Even when there is a positional shift between the object noun and the completive particle, as illustrated below, rồi still remains at the right edge of the sentence:
a. Tôi
đã [viết
bài xong] rồi
'Is DA write paper finish already
b. Tôi đã [viết xong bài] rồi. Particle-object - rồi 1s DA write finish paper already
'I have already written up papers.' 
Moreover, unlike the completive particle xong, the adverb rồi cannot intervene between the verb and the direct object.

(19) a.

$$
\begin{aligned}
& \text { Tôi đã viết } \quad \begin{array}{l}
\text { xong } \\
\text { 1s DÀi write finish paper }
\end{array} \text { Verb -Particle - object } \\
& \text { 'I have written up papers.' }
\end{aligned}
$$

b. * Tôi đã viết rồi bài *Verb-Rồi - object

1s DA write already paper

(Intended:) 'I have written up papers.'

The same holds for other prototypical manner adverbs, such as nhanh chóng ('quickly'), they cannot be positioned between the verb and its noun complement, either:

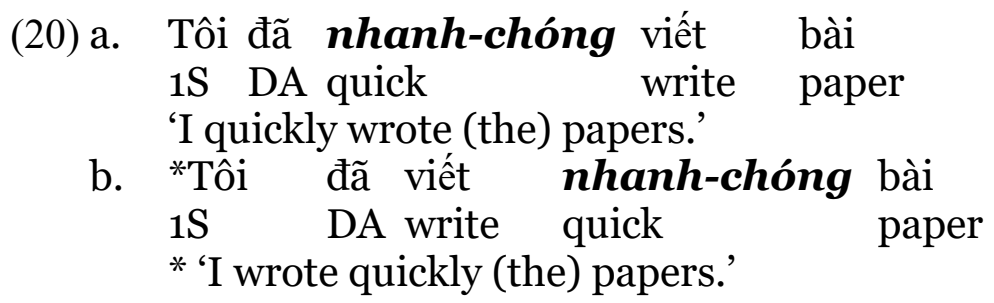

This characteristic is also shared by English adverbs, a commonality that is presumably due to the absence of finite verb-raising in the two languages (Pollock 1989).

(21) a. Alice quickly wrote the paper.

b. *Alice wrote quickly the paper.

The fact that telic particles can appear in what is otherwise an opaque syntactic position suggests that they deserve special treatment. 7

Another piece of evidence to differentiate genuine telic particles from the adverd rồi ('already') is found in the fact that whereas rồi can freely combine with any types of predicate (either durative or punctual predicates); telic particle xong ('finish') mostly occurs with durative dynamic predicates (or accomplishment in Vendler (1957)'s terminology), and is incompatible with punctual predicates, as illustrated below:

$$
\begin{aligned}
& \text { (22) a. Nó đã } \quad \text { sửa xe rồi. Durative verb - rồi } \\
& \text { 3s DA fix car already } \\
& \text { 'He has already fixed the car.' }
\end{aligned}
$$

\footnotetext{
7 Tue Trinh (p.c.) pointed out that adverbs, in fact, can appear between the verb and the direct object in languages like German. However, to us this descriptive fact only means that the lexical verb in German raises cross the adverbs to a higher functional position. English and Vietnamese lexical verbs, on the other hand, do not move that high. Therefore, in a language that lacks of lexical verb movement to a position outside of the VP like Vietnamese, the position of the telic particles is clearly of interest. See Phan (2013 a, b) for detailed analysis of those telic particles in Vietnamese.
} 


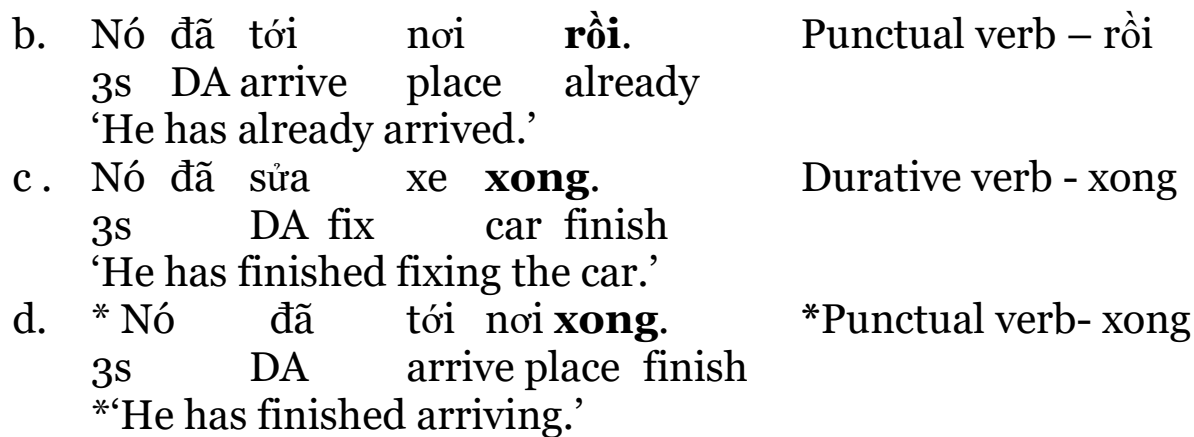

(Examples of Cao 2000:11)

These examples illustrate that the adverb rồi ('already'), though denoting the anteriority or perfectivity interpretation, does not behave distributionally as a nuclear functional category. Compared to those genuine telic particles, it stays peripheral with respect to the temporality and aspectuality of the predicate.

Thus, the distributional and interpretational properties of those tense/aspect markers, both in pre-verbal and post-verbal domains, suggest that unlike the peripheral adverbs, they are closely associated with the predicate as a verbal functional category.

\section{Non-optionality}

Another reason to object to the existence of tense and/or aspect as a functional category in Vietnamese comes from the observation that those free temporal/aspectual morphemes that do exist in the language tend to be optional. In this section, we discuss the question of whether or not they are truly optional in Vietnamese (as commonly assumed in other areallyrelated languages, see Liu 2015, Yang 2011, 2014, a.o.). The question is if a bare verb can be interpreted with a tensed and aspectual reading, why then do these tense/aspect markers exist in the first place? In this section, we show that there is solid evidence that the Vietnamese tense/aspect markers are not truly optional at all, but rather contribute their own distinct syntax and semantics. We discuss the pre-verbal and post-verbal domain in turn.

It turns out that in the pre-verbal domain the presence or absence of the perfect marker đã does create a significant difference for the temporality and aspectuality of the sentence, depending on what type of verb phrase it co-occurs with. Đã can assert the completion of the eventuality when it precedes achievement verbs:

$$
\begin{aligned}
& \text { a. Andy Murray doạt giải. } \\
& \text { Andy Murray win award } \\
& \text { 'Andy Murray won the award.' }
\end{aligned}
$$


$\begin{array}{llll}\text { b. Andy Murray đã } & \text { đoạt } & \text { giải. } \\ \text { Andy Murray ant } & \text { win } & \text { award } \\ \text { 'Andy Murray has won the award.' } & \end{array}$

Without đã, the sentence simply refers to the event of Andy Murray winning the award which is most likely taking place in the past. In the presence of $đ \tilde{a}$, the sentence not only asserts that the winning of Andy Murray has been realized before the default utterance time, but also has an additional implication that Andy Murray's winning the award did not take place previously.

On the other hand, when đã appears before accomplishment verbs, it does not signal the completion, but only the termination of the eventuality (namely, the event has taken place and terminated without having reached its final end point).
a. Tôi viết bài ở văn phòng. 1s write paper at office 'I wrote/will write/write paper(s) at the office.'
b. Tôi đã viêt bài ở văn phòng. 1s DA write paper at office 'I wrote paper(s) at the office.'

Without đã , the writing event can be freely located either in the past or in the future, or can even be interpreted as a habitual event. In the presence of $\approx \tilde{a}$, the event is fixed in the timeline, đã specifies that the event has started, but interestingly it does not signal the completion of the event, since the endpoint can be cancelled.

$$
\begin{aligned}
& \text { Tôi đã viết bài ở văn-phòng nhưng vẫn chưa xong. } \\
& \text { 1s DA write paper at office but still NEG finish } \\
& \text { 'I wrote paper(s) at the office but I haven't finished it/them yet.' }
\end{aligned}
$$

What is more, when đã co-occurs with stative predicates, it signals the inchoativity of the situationality.
a. Ngoài đường trời sáng. Out road sky bright
'It is bright out there'.
b. Ngoài đường trời $\boldsymbol{d} \tilde{\boldsymbol{a}}$ sang. Out road sky DA bright 'It got bright out there'.

(Example of (Trần, K.P. 2008:73)

Without đã, the sentence simply indicates the current state of the sky being bright without referring to when it actually begins or terminates. With đã, the sentence signals a change of state: the sky got bright before 
the default utterance time, but there was an earlier time when it didn't. Again when the event terminates is left open.

Similarly to the pre-verbal markers, the presence or absence of the postverbal telic particles also yields a clear contrast for the temporality and aspectuality of the sentence. These particles occur between the main verb and the direct object and serve to convert an atelic event into a telic one:
a. Chú bò tìm bạn. cls cow seek friend 'The cow looked for his friend.'
b. Chú bò tìm ra bạn. ${ }^{8}$ cls cow search out friend 'The cow found his friend.'

In the absence of $r a$ ('out'), we simply have an event of a cow looking for his friend. The addition of the particle ra contributes a connotation of 'culmination' (or 'completeness') to the event.

All of these facts indicate that the occurrence of these tense/aspect markers is not totally optional, but is sensitive to various semantic and syntactic factors.

As a final note on their non-optionality, it should be pointed that there are contexts in which the use of these items is obligatory. For instance, as convincingly shown by Nguyễn Minh Thuyết (1995), some cognitive predicates such as biết ('know'), thấy ('feel'), yêu ('love'), ghét ('hate'), obligatorily require the co-occurrence of the future marker sẽ even in the presence of the temporal adverb 'tomorrow':
(28) a. *Đừng lo, ngày mai anh thấy khoẻ hơn nhiều. don't worry, tomorrow $2 \mathrm{~S}$ feel good more many 'Don't worry, you will feel much better tomorrow.'
b. Đừng lo, ngày mai anh sẽ thấy khoẻ hơn nhiều. don't worry, tomorrow $2 \mathrm{~S}$ fut feel good more many 'Don't worry, you will feel much better tomorrow.'

The example (28) indicates two crucial points: (unlike what has been commonly assumed) the presence of temporal adverbials is not always sufficient to anchor the situation in the future time, (ii) and the presence of the future tense marker is not always optional.

In sum, there are different pieces of evidence that the tense and aspect markers in Vietnamese are not optional but rather contribute their own set of distinct properties to the syntactic structure of the sentence.

\footnotetext{
8 The contrast between 'tìm' vs. 'tìm ra' in Vietnamese is similar to the synthetically expressed contrast in English between 'look for' vs. 'find' (and similarly between look vs. see, listen vs. hear). For that, Vietnamese is more morphologically transparent than English.
} 


\section{The hierarchy of tense and aspect}

So far, we have shown that tense and aspect markers in Vietnamese are neither peripheral nor are they optional - at least in certain contexts. In this section, we demonstrate that they also conform rather strictly to the hierarchical order of tense and aspect displayed cross-linguistically (Cinque 1999).

As for the pre-verbal domain, the three tense/aspect markers can be arranged in a strict sequence as below:

$$
\text { Future sẽ > Perfect đã > Durative đang }
$$

From a syntactic point of view, we propose that among the three markers, đang as a durative aspect marker occupies the lowest position, the future tense marker se is in the highest position, with the perfect marker $đ \tilde{a}$ occupying an intermediate position.

The first piece of evidence for this hierarchy comes from the fact that when the three elements co-occur, đang always stays lowest, i.e., đang can never precede sẽ and đã:

(30) a. Giờ này ngày-mai tôi sẽ đang tắm nắng ở Hawaii. hour dem tomorrow 1sSE DANG bath sun in Hawaii 'By this time tomorrow I will be taking a sunbath in Hawaii.'

b. *Giờ này ngày-mai, tôi đang sẽ tắm nắng ở Hawaii hour dem tomorrow 1sDANG SE bath sun in Hawaii 'By this time tomorrow I will be taking a sunbath in Hawaii.'
a. Lúc tôi đến, nó đã đang ngủ rồi. 9 When $1 \mathrm{~S}$ come, $3 \mathrm{~s}$ DA DANG sleep already 'When I came, he had been sleeping.'
b. *Lúc tôi đến, nó đang đã ngủ rồi. When I come, 3s DANG DA sleep already
'When I came, he had been sleeping.'

The lower position of đang relative to sẽ and đã is confirmed by the fact that đang is the only element of the three TAM markers discussed so far

9 The strict ordering constraint between đã and đang in Vietnamese can also be found in many other languages, where PERF $>$ PROG is the legitimate order, but PROG $>$ PERF is not:

(i) a. John has been writing a letter.

b.* I am nearly having written/read this paper. (English,Mittwoch 1988:238, 243)

(ii) 'i tè po yirè ke-ko.' prn fut perf prog go

'I will have been going.'

(Temne, Cinque 1999:193)

(iii) 'shamu-ju-shka-ni.' come-prog-perf-prn

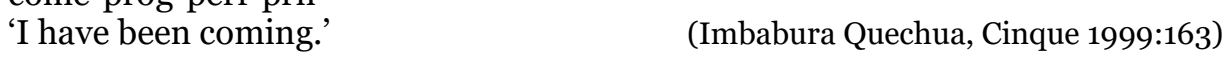


that can appear to the right of both the sentential negation marker không and the aspectual adverb vira ('just'). This is illustrated by the minimal contrasts in (35) below:

(32) a. Tôi đang không làm việc đó.

1s DANG neg do job that

'I am not doing it.'

b. Tôi không đang làm việc đó. 1s neg DANG do job that

'I am not doing it.'

c. Tôi sẽ không làm việc đó. 1s SE neg do job that 'I won't do it.'

d. *Tôi không sẽ làm việc đó. 1S neg SE do job that (Intended:) 'I won't do it.'

e. Tôi đã không làm việc đó. 1s DA neg do job that 'I didn't do it.'

f. *Tôi không đã làm việc đó. 1s neg DA do job that

(Intended:) 'I didn't do it.'

(33) a. 'Người mà (đang) vừa (đang) ăn cơm vừa xem tivi đó.' person rm DANG just DANG eat rice just watch TV dem 'the person who was just eating dinner and watching TV'

b. 'Người mà ?(sẽ) vừa ${ }^{*}(\mathbf{s e ̃})$ ăn cơm vừa xem tivi đó'.10 person rm SE just SE eat rice just watch TV dem 'the person who will just eat dinner and watch TV'

c. 'Người mà ?(đã) vừa *(đã) ăn cơm vừa xem tivi đó'. person rm DA just DA eat rice just watch TV dem 'the person who has just eaten dinner and watched TV'

(Examples from Duffield (2017))

From those pieces of evidence, it is obvious that đang is structurally lower than sẽ and đã.

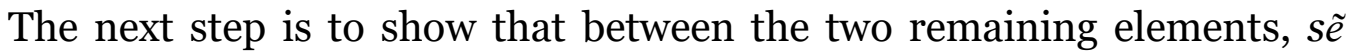
occupies a higher position than that occupied by đã. Our main argument comes from their interactions with sentential negation and modal markers. Whereas in affirmative contexts $\tilde{a} \tilde{a}$ is ambiguous between a perfect and a past tense reading, ${ }^{11}$ in contexts of sentential negation, đã may only be interpreted as a past tense marker (Trinh 2005):

10 Although judgements vary on the absolute acceptability of (33 b-c), our point is secure as long as the examples with đã and sẽ following the adverb vira sound worse than the counterparts with đã and sẽ preceding the adverb vìa. The same holds true for other examples in this section. 
(34) a. Nó đã viết bài.

3s DA write paper

EITHER 'He wrote papers.'

OR: 'He has written papers.'

b. Nó đã không viêt bài

$3 \mathrm{~S}$ DA NEG write paper

'He didn't write papers.'

NOT: 'He has not written papers.'

The minimal contrast above demonstrates that đã loses its aspectual reading in negative declaratives. ${ }^{12}$ The interpretation of $s \tilde{e}$, by contrast is unaffected by the presence of negation, as shown below:

$\begin{array}{ll}\text { (35) a. } & \text { Nó } \quad \text { sẽ viết bài. } \\ & 3 \mathrm{~S} \text { SE write paper } \\ \text { 'He will write papers.' } \\ \text { b. Nó Sé không viêt bài } \\ \text { 3S SE neg write paper } \\ \text { 'He won't write papers.' }\end{array}$

This contrasts suggests that $s \tilde{e}$ is not within the c-commanding domain of negation, while $\tilde{\alpha} \tilde{a}$ is. Therefore, it may be concluded $s \tilde{e}$ is base-generated in a higher position than đã.

Another piece of supporting evidence for the higher position of se in relation to đã and đang comes from their interaction with modal markers: whereas modals can either precede or follow đã and đang, they obligatorily follow sẽ:

(36) a. Nó đã phải chịu-đựng quá nhiều ở đó rồi. 3s DA modal suffer too much at there already 'He had to suffer too much in there.'

b. "Để làm được điều này máy điện-thoại của anh-em prep do get thing this CLF phone of $2 \mathrm{~S} . \mathrm{PL}$

phải đã được jailbreak trước”. ${ }^{13}$

modal DA get jailbreak before

'In order to do that, your cellphones have to be jail-broken before.'

\footnotetext{
11 See Musan (2001) for discussion of a similar effect of negation on the perfect morpheme in German. Also, see Cinque (2006) for more supporting evidence from Turkish. For instance, according to Cinque,the morpheme 'di' in Turkish is also systematically ambiguous between a past tense reading and a perfect reading: 'Hasan baligi ye-di.' can be read as 'Hasan ate the fish.' OR 'Hasan has eaten the fish.' (Cinque 2006:184)

12 See Trinh (2005), Duffield (2013, 2017), Phan (2013a), Phan \& Duffield (2016), for discussion of how and why this happens.

13 Source: http://forum.mysamsung.vn/showthread.php?88199 (Accessed 20 June 2013).
} 
(37) a. Có rất nhiều vấn-đề mà trái-đất đang phải đối-mặt. existverymany problemRM earth DANG modal face 'There are many problems that the earth has to face'.

b. Quanh ta vẫn còn rất nhiều trẻ-em phải đang Around 1P still existverymany children modal DANG chống-chọi với cơn đau hàng giờ, hàng ngày".14 fight with CLFpain every hour every day 'There are still many children who have to be fighting with their pain every hour every day around us.'

(38) a. Em sẽ phải quên anh đi. 2S SE modal forget 1s prt 'You will have to forget me.'

b. *Hai năm nữa em phải sẽ tốt-nghiệp. Two year more $2 \mathrm{~s}$ modal $\mathrm{SE}$ graduate 'Your will have to graduate in two years'.

Overall, we have seen that the syntactic order of the three markers really co-varies with their interpretive features. Specifically, the essentially temporal nature of the future sẽ enables it to be base generated as the highest, while the purely aspectual essence of the durative đang keeps it stay lowest, and also the compositional semantics of the perfect đãa restricts it to the middle position. The data presented so far provide strong semantic and syntactic grounds to believe that there is a hierarchy among those pre-verbal tense/aspect markers.

As for the post-verbal domain, we have already seen in (4) a list of different particles which convey the telicity of the predicate. Given the hierarchical arrangement of pre-verbal particles, it may be wondered whether the same applies postverbally.

As the list in (4) shows, there are two main groups of telic particles: the completive particles which include ra (out), xong (finish) and hêt (end); and the resultative particles such as đurọc (get), phái (have.to). ${ }^{16}$ The two groups are not only semantically distinct (as seen from their names), but they also exhibit distinct syntactic behaviors, for only the completive group (though not all of its members) allows word-order alternations. Specifically, while the object can freely precede or follow the completive particles, resultative particles prohibit object raising (in the sense that in the case of object shift, the aspectual reading of the resultative particles will be lost), as indicated below:

14 Source: http://hieuvetraitim.org/tintucchitiet.php?id=525 (Accessed 20 June 2013).

15 See Phan (2013a), Phan \& Duffield (in prep.) for the detailed analysis of the compositionality of đã.

16 As noted in Phan (2013b), there exists particle which neither belong to the completive nor the resultative groups, for instance, the continuative lại (again). 
(39) a. Nó đã lau bàn xong.

3s DA wipe table finish

'He wiped down the table (He finished wiping the table).'

b. Nó đã lau xong bàn.

3s DA wipe finish table

'He wiped down the table (He finished wiping the table).'

(40) a. Cô-ấy kiếm được việc.

3s seek get job

'She found a job.'

b. Cô-ấy kiếm việc được.

3s seek job get

'She can find a job.'

It is interesting to observe that the two kinds of particles can in fact combine together in one cluase:
a. Cuối-cùng nó cũng lau xong được cái bàn. final $3 \mathrm{~s}$ also wipe finish get CLFtable 'He finally finished wiping down the table.'
b. Họ đã tìm ra được cách chữa bệnh AIDS 3p DA seek out get way treat disease AIDS 'They have found the cure for AIDS.'

In all the above examples, resultative particles always follow the completive particles. The reverse ordering leads to ungrammaticality:
*Cuối-cùng nó cũng lau được xong cái bàn. final 3s also wipe get finish CLFtable 'He finally finished wiping down the table.'
b. *Họ đã tìm được ra cách chữa bệnh AIDS 3p DA seek get out way treat disease AIDS 'They have found the cure for AIDS.'

This suggests that the resultative aspect is structurally lower than the Completive aspect in Vietnamese. Similarly, English also exhibits the resultative-last constraint, i.e., the resultative particle also cannot precede the directional particle phenomenon:

(43) a. 'He put the book back up on the shelf.'

b. '** He put the book up back on the shelf.'

(Nicol 2002:183-184)

So far, we have sufficient evidence to argue that all tense and aspect markers-both pre- and post-verbal-in Vietnamese conform to the 
universal functional sequence given in Cinque (1999):

(44) Future $s \tilde{e}>$ Perfect $đ \tilde{a}>$ Durative đang $>$ Verb >Completive $x$ ong $>$ Resultative đurọc

The result in (44) displays a transparent semantics-syntax mapping in Vietnamese. In particular, Vietnamese presents an ideal object language in which to examine the parallels between syntax and semantics. From a semantic point of view, the Vietnamese morphemes listed in (4) can be classified into three main groups: The Tense group includes the the future se्e, the Viewpoint Aspect group consists of the perfect đã and the durative đang, and the Situation Aspect includes the completive/resultative particles. ${ }^{17}$ From a syntactic perspective, we have shown that these three groups obey a strict order, namely, from the top to the bottom, we have Tense markers $>$ Viewpoint Aspect markers $>$ Situation Aspect markers. That is to say, the syntactic order of the those markers directly correlates with their interpretive features in Vietnamese (which stands in contrast to the semantics/syntax mismatch obeserved in Chinese: see Tsai 2008).

\section{Discussion and conclusion}

The contribution of our paper can be summed up as follows. First of all, we argue against the more traditional analyses of Vietnamese as a tenseless language. We have shown that contrary to what has been widely assumed, there are cases in which the presence of temporal adverbial expressions (such as tomorrow) does not suffice to anchor the situation in the time line; in such cases, Vietnamese must rely on temporal and aspectual auxiliaries/particles. We also have argued that those temporal and aspectual auxiliaries/particles in Vietnamese are genuine tense and aspect markers, in as much as: (i) they are not peripheral but rather closely associated with the verb, (ii) they are not optional as commonly assumed, and crucially, (iii), they are hierarchically ordered, strictly following the universal functional sequence of tense and aspect cross-linguistically (Cinque 1999).

Based on this, we conclude that Vietnamese indeed has tense and aspect as independent functional categories.

The question of whether an under-studied language has tense/aspect also arises in a typological perspective. Addressing the same research question, Nordlinger and Sadler (2008) point out:

'To put it in a broader perspective, [...] to what extent is a category to be defined in terms of the internal oppositions of the language itself [...], and to what extent should we impose preconceived notions of categories and their boundaries? These seem to us to be fundamental

17 See Phan (2013 a, b), Phan \& Duffield (in prep.) for a detailed discussion of the semantics of these elements. 
and difficult methodological points that we constantly face in linguistic research, most especially on underdescribed languages [...]. Nordlinger and Sadler (2008: 329)

In this study, we follow a tertium comparationis method (Humboldt 1829, Cinque 1999, Wiltschko 2014), in which we do not compare Vietnamese directly to Indo-European languages, but to the third party, namely the universal functional sequence of functional categories (Cinque 1999). It reveals that languages are more alike than we think, and Vietnamese is not so exotic after all.

\section{References}

Binnick, R. 2001. Temporality and Aspectuality. In M. Haspelmath, K. Ekkehard, O. Wulf, and W. Raible (Eds.) Language Typology and Language Universals. Berlin: Walter de Gruyter, pp.557-567.

Bùi, Đ. T. 1967. Văn phạm Việt Nam. Sài Gòn: Nhà sách Khai Trí..

Cao, X.H. 1998. Về ý nghĩa thì và thể trong tiếng Việt. Ngôn ngũ, 5, pp. 1-31.

Cao, X. H. 2000. Ý nghĩa hoàn tất trong tiếng Việt. Ngôn ngũu, 5, pp. 9-15.

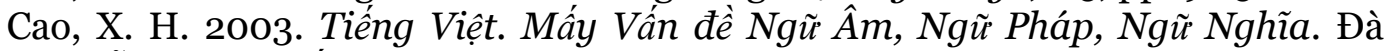
Nẵng: Nhà xuất bản Giáo dục.

Cinque, G. 1999. Adverbs and Functional Heads: A Cross-linguistic Perspective. New York: Oxford University Press.

Cinque, G. 2006. Restructuring and Functional Heads. New York: Oxford University Press.

Cinque, G. \& Rizzi, L. 2008. The cartography of syntactic structures. In: V. Moscati (Ed.). CISCL Working Papers on Language and Cognition, Vol. 2, MITWPL, pp. 43-59..

Comrie, B. 1976. Aspect. Cambridge: Cambridge University Press.

Đào, T. 1979. Về các nhóm từ có ý nghĩa thời gian trong tiếng Việt. Ngôn ngũu, 1 , pp. 40-45.

Do-Hurinville, D.T. 2009. Vietnamese temporal structures with the TAM markers 'đã, rồi, đang, vừa, mới, sắp, sẽ'. Paper presented at the Workshop on Linguistics of Vietnamese, $6^{\text {th }}-7^{\text {th }}$ July, University of Stuttgart.

Duffield, N. 1999. Final modals, adverbs and antisymmetry in Vietnamese. Revue Québécoise de linguistique, 27, pp. 91-128.

Duffield, N. 2007. Aspects of Vietnamese Clausal Structure: separating tense from assertion. Linguistics, 45 (4), pp. 765-814.

Duffield, N. 2013. Head-First: On the head-initiality of Vietnamese clauses. In D. Hole \& E Löbel (Eds.) Linguistics of Vietnamese: an International Survey. Berlin: de Gruyter Mouton, pp. 127-155.

Duffield, N. 2017. On what projects in Vietnamese. Lingbuzz/o03439 (Ms. Konan University).

Duffield, N. \& Phan, T. 2010. Aspect exposed: On the syntactic representation of tense and aspect in Vietnamese. Paper presented at SEALS 20, $10^{\text {th }}-11^{\text {th }}$ June, Zurich.

Foley, W. A. \& Van Valin, R. 1984. Functional syntax and universal grammar. Cambridge: Cambridge University Press. 
Fukuda, S. 2007. The syntax of telicity in Vietnamese. In: E. Bainbridge \& B. Agbayani (Eds.). Proceedings of the 34th Western Conference on Linguistics (WECOL 2006). California State University, Fresno, pp. 109-120.

Hengeveld, K. 1989. Layers and Operators in Functional Grammar. Journal of Linguistics 25, pp.127-157.

Hengeveld, K. 2011. Grammaticalisation of Tense and Aspect. In B. Heine \& H. Narrog (Eds.), The Oxford Handbook of Grammaticalization. New York: Oxford University Press, pp. 462-471.

Humboldt, W. 1963[1829]. Über die Verschiedenheiten des menschlichen

Sprachbaues. In A. Flitner \& K. Giel (Eds.) Schriften zur Sprachphilosophie, Darmstadt: Wissenschaftlich Buchgesellschaft, pp. 144-367.

Klein, W. 1994. Time in Language. London: Routledge.

Liu, M. 2015. Tense and Aspect in Mandarin Chinese. In W. Wang \& C. Sun (Eds). The Oxford Handbook of Chinese linguistics. Oxford: Oxford University Press, pp. 274-290.

Lo-Cicero, M.H. 2001. L'expression du temps et de l'aspect du verbe vietnamien. The Review of Vietnamese Studies 1, pp. 1-12.

Mittwoch, A. 1988. Aspects of English Aspect: On the interaction of Perfect, Progressive, and durational phrases. Linguistics and Philosophy, 11,pp. 203254.

Musan, R. 2001. The Present Perfect in German: Outline of its semantic composition. Natural Language and Linguistic Theory, 19, pp. 355-401.

Nguyễn, Đ.D. 1996. Biểu hiện và nhận diện thời gian trong tiếng Việt. Ngôn ng ũ, 3 , pp. 5-13.

Nguyễn, K.T. 1997. Nghiên Cúu về Ngĩ Pháp Tiếng Việt. Hà Nội: Nhà xuất bản Giáo dục.

Nguyễn, V.T. 2003. Tiếng Việt Hiện Đại. Hà Nội: Nhà xuất bản Khoa học Xã hội.

Nguyễn, M. T. 1995. Các tiền phó từ chỉ thời thể trong tiếng Việt. Ngôn ngũu, 2, pp. 1-10.

Nordlinger, R. \& L. Sadler. 2008. When is a temporal marker not a tense?

Reply to Tonhauser 2007. Language, 84(2), pp. 325-331.

Nicol, F. 2002. Extended VP-shells and the verb-particle construction. In N. Dehé \& R. Jackendoff et al (Eds.). Verb-Particle Explorations . Berlin/New York: Mouton de Gruyter, pp. 165-190.

Panfilov V.X. 2002. Một lần nữa về phạm trù thì trong tiếng Việt. Ngôn ngũu, 7, pp. $1-7$.

Panfilov, V.X. 2008. Co Cấu Ngũ Pháp Tiếng Việt. Translated by Nguyễn, T.M. Hà Nội: Nhà xuất bản Giáo dục.

Phan, K. 1997. Việt Ngũ Nghiên Cúu. Đà Nẵng: Nhà xuất bản Đà Nẵng. First published in 1955, Hà Nội: Nhà xuất bản Văn nghệ.

Phan, T. 2013a. Syntax of Vietnamese Aspect. PhD, University of Sheffield.

Phan, T. 2013b. The projection of Inner Aspect in Vietnamese. Journal of Portuguese Linguistics. A thematic issue on Tense and Aspect in Generative Grammar, 12(1), pp. 41-62.

Phan, T. \& Duffield, N. 2016. On the negation restriction of the perfect in Vietnamese - a nanosyntax approach. Paper presented at Chronos 12, Caen University, 15-17 June 2016.

Phan, T. \& Duffield, N. (in prep). On the compositionality of the so-called perfect auxiliary in Vietnamese. To be submitted to A. Patard, R. Peltola \& E. Roussel (eds.), Crosslinguistic perspectives on grammatical aspect. Cahiers Chronos. Brill. 
Pollock, J.V. 1989. Verb-movement, UG and the structure of IP. Linguistic Inquiry, 20, pp. 365-424.

Smith, C. 1997. The Parameter of Aspect. Dordrecht: Kluwer Academic Publishers.

Thompson, L.C. 1965. A Vietnamese Grammar. Seattle/London: University of Washington Press.

Trần, T. K; Bùi, K. \& Phạm, D.K. 1940. Văn Phạm Việt Nam. Sài Gòn: Nhà xuất bản Tân Việt.

Trần, K.P. 2008. Ngũ pháp tiếng Việt, nhũng vấn đề về thòi và thể. Hà Nội: Nhà xuất bản Giáo dục.

Trinh, T. 2005. Aspect of Clause Structure in Vietnamese. MA, Humboldt University.

Tsai, D. 2008. Tense Anchoring in Chinese. Lingua 118, pp. 675-686.

Vendler, Z. 1957. Verbs and Times. The Philosophical Review, 66(2), pp.143-160.

Wiltschko, M. 2014. The Universal Structure of Categories: Towards a Formal Typology. Cambridge: Cambridge University Press.

Yang, S. 2011. The parameter of temporal endpoint and the basic function of-le. Journal of East Asian Linguist 20, pp. 383-415.

Yang, S. 2014. The L2 Acquisition of the Chinese Aspect Marking. In W. Aroonmanakun, P. Boonkwan, T. Supnithi (Eds.), Proceedings of 28th Pacific Asia Conference on Language, Information and Computation. Department of Linguistics, Faculty of Arts, Chulalongkorn University, pp. 299-308.

\section{Acknowledgements}

This work is funded by Vietnam National Foundation for Science \& Technology Development (NAFOSTED) grant \# 602.02-2018.300 [first author]. 